\section{Strategy or Legitimacy? Analysis of the Role of Institutional Development Plans in Brazilian Universities}

\author{
Maurício Andrade Lima ${ }^{1}$ \\ mauricio.lima@unisul.br | (100000-0002-4287-5791 \\ Fernando Antônio Ribeiro Serra ${ }^{2}$ \\ fernandorserra@gmail.com | (1D)0000-0002-8178-7313 \\ Thiago Coelho Soares ${ }^{1}$ \\ prof.tcoelhos@gmail.com | (D)0000-0002-7470-6271 \\ Carlos Rogerio Montenegro de Lima ${ }^{1}$ \\ carlos.montenegro@unisul.br | (1)0000-0003-0353-5097
}

\begin{abstract}
The aim of this study is to analyze whether Institutional Development Plans (IDP) are strategic documents or simply a response to seeking legitimacy in the face of regulatory pressures. This is a qualitative study based on information from 20 IDPs of Brazilian universities, categorized as private, public, community, or confessional. To analyze the IDPs, the content analysis methodology was used. As a result, it was found that most IDPs are much more descriptive documents, with operational goals and plans, than documents with strategic characteristics. On the other hand, in most of the documents analyzed, there was evidence of the importance and relevance of constructing an IDP as a benefit for the management and the university organization as a whole. It was concluded that IDPs tend to be documents that seek to provide universities with legitimacy in relation to the actors involved. In other words, they converge towards institutional isomorphism. Thus, they are not prepared, and used only due to institutional demands, but mainly due to legal impositions.
\end{abstract}

\section{KEYWORDS}

Isomorphism, Resource-based View, Strategy, Universities
${ }^{1}$ Universidade do Sul de Santa Catarina, Palhoça, SC, Brasil

${ }^{2}$ Universidade Nove de Julho, São Paulo, SP, Brasil

Received: $12 / 20 / 2018$ Revised: 03/25/2019. Accepted: 05/06/2019. Published Online: $12 / 09 / 2019$ DOI: http://dx.doi.org/10.15728/bbr.2020.17.1.4 


\section{INTRODUCTION}

In response to the rapid growth of the Brazilian educational sector, in 2004 the Ministry of Education (MEC) created the Higher Education Evaluation System (SINAES), which includes a model for the drafting of an Institutional Development Plan (IDP). An IDP can be viewed as a strategic planning tool for High Education Institutions (HEI), describing the mission, goals, actions, objectives, deadlines, and results to be achieved. This information, if well used, would help HEI remain competitive in terms of efficient control of their financial resources, enabling investments in infrastructure, qualified professionals, and new technology (Almino Francisco, Otani, Helou, \& Michels, 2011).

Given the importance of HEI to society, better management of these organizations, through the adequate use of an IDP, has shown to be relevant in the literature. Some approaches have been observed that strive to understand how HEI, whether public, private, community, or confessional, use this document to enact their strategies, or attempt to identify the importance of formulating strategy to aid the drafting of an IDP (Silva, Melo, \& Ramos, 2013; Samonetto \& Campos, 2013). Other studies seek to evaluate whether HEI comply with the requirements and dimensions established by the Ministry of Education and how the legal framework impacts the relationship between strategic planning and its reproduction in the drafting of an IDP (Dalmagro \& Rausch, 2012). Studies have also been identified that show that an IDP is the result of a collective construction. Furthermore, the limits and possibilities of an IDP are understood as a managerial tool in the view of teaching and technical-administrative staff (Mizael, Pereira, Vilas Boas, \& Ferreira, 2012).

In the present study, on the one hand, an effort is made to understand whether the strategic actions of HEI, as expressed in their IDPs, reflect institutional pressures, with their strategies converging to gain legitimacy. On the other hand, despite institutional pressures, the expansion of the sector, growing competition, and competitiveness force IDPs to reflect the need to differentiate strategically, using their resources and capabilities.

With the possibility of the IDP reorganizing and planning the academic and administrative management of HEI as well as considering the need to gain further knowledge regarding a theme embedded in a competitive context which is intensely regulated by the state, the present study was conducted to answer the following research question. Do the strategic adaptations of HEI, as expressed in their IDPs, reflect only institutional pressures, leading them to converge their actions, or do they characterize the strategic need to differentiate through the development of their resources and capabilities?

The article begins with the characterization of the higher education sector in Brazil, moving on to provide details of the relationship between the SINAES, the IDP, and the complex university organization. This is followed by a theoretical discussion, and some writing on the gaps left open by empirical studies on which the proposed model is based. The methodology, results, and discussion are then presented. Finally, the contributions of the study are summarized, followed by challenges for future studies.

\section{THE BRAZILIAN HIGHER EDUCATION SECTOR}

Brazil is the fifth largest market for higher education in the world, and the largest in Latin America, with approximately 7.8 million students enrolled. Around $83.9 \%$ of Brazilian HEI are universities, but only $28.6 \%$ of the students are enrolled in them. The 195 universities in Brazil represent $8.2 \%$ of all HEI, with $53.2 \%$ of enrolments registered in undergraduate courses. Almost 
BBR

17

68

all university courses (90\%) are regular. Most universities $(56.9 \%)$ are public. The predominant academic course is a bachelor's degree (55.6\%) (MEC, 2014).

Despite the number of students enrolled in higher education in recent years, only $17.8 \%$ of the Brazilian population aged 18 to 24 were enrolled in HEI in 2012 (MEC, 2014), far below the goal of $33 \%$ set by the Federal Government for 2020 .

Until 1996, the sector was subject to strong regulatory restrictions that hindered the expansion of courses offered by private HEI, despite insufficient public investments throughout the sector (Salviani, 2010). With the promulgation of the Law of Directives and Bases of National Education (LDB) in December of 1996, a set of measures was presented to attract private investment in the sector. These included the flexibilization of regulatory restrictions on the opening of courses and institutions, and this regulation of the law allowed HEI to be recognized as for-profit businesses (Carvalho, 2013). Due to the changes in the legal framework of the sector and the possibility of the constitution and entry of private HEI, changes and new alternatives were seen. These included various forms of funding, such as the University for All Program (PROUNI) and the Student Funding Program (FIES). The growth of Distance Learning led to a representative growth in the target audience of HEI, and the fragmentation of the market enabled alternatives for growth through mergers and acquisition (Ristoff, 2011).

Despite the recognition of the advances resulting from this expansion of higher education and its importance to the social and economic development of Brazil, the higher education system, in general, needs to face complex challenges. These include growing access and greater equity in conditions of access, high-quality university degrees, as well as the diversification of courses on offer and levels of graduation. They also have to address the qualification of teaching professionals, guaranteed financing, especially for the public sector, the employability of graduates, the social relevance of the programs on offer, and stimulus for scientific and technological research (Ristoff, 2011).

Owing to the changes in the legal framework and its developments, in parallel, Brazil has sought different forms and mechanisms for assessing higher education. Consequently, in 2004, the National Higher Education Evaluation System (SINAES) emerged. Its purpose was to serve as a truly integrative system that guaranteed information and analyses of all higher education, thus enabling education policies to be established at the national level through pertinent agencies, and at the institutional level, as articulated by HEI (Polidori, Marinho-Araujo, \& Barreyro, 2006). SINAES is made up of three main components: the evaluation of HEI, courses, and student performance. The SINAES assesses all aspect that revolve around these three axes. Therefore, they seek to articulate organizational evaluation and the evaluation of courses and students with regard to research, teaching and extension, social responsibility, student performance, the management of institutions, teaching staff, installations, and other aspects (Lehfeld, Gabarra, Costa, \& Silva Sousa, 2010).

The SINAES is composed of a set of complementary tools: self-evaluation, external evaluation, evaluation of undergraduate courses, and information tools, such as a census. According to the Anísio Teixeira National Institute for Educational Studies and Research (INEP, 2015), selfevaluation is an internal process that can be used as an important tool for decision making, since it helps to identify weaknesses and potential in the university through 10 dimensions that constitute the SINAES. In the general guidelines for the self-evaluation scripts of HEI, the INEP (2015) presents some directives: existence of a coordination team; participation of members 
of the institution; clear commitment of HEI managers; and valid and reliable information and effective use of results.

Regarding external evaluation, the INEP designates committees, using as a reference the quality standards for higher education outlines in the evaluation tools and self-evaluation reports. Irrespective of their approach, external evaluations, through a multidimensional approach, seek to integrate their formative and regulatory natures through a systemic view. In general, "evaluation processes should constitute a system that allows the integration of the various dimensions of the reality in question, ensuring conceptual, epistemological and practical coherence and the achievement of the goals of the diverse instruments and modalities" (INEP, 2015).

As for the National Examination of Student Performance (Enade), it seeks to evaluate the success of graduates in regards to program content, skills, and competencies acquired during their courses. This assessment is compulsory, and its result must be entered into the graduate's educational record. The first version of this exam was created in 2004 and must be applied at least once every three years in each field of knowledge (INEP, 2015).

The Preliminary Course Concept (CPC) is a quality indicator used to assess undergraduate courses. "It is calculated and published in the year after the Enade, based on the evaluation of student performance, with added value for the formative process and input regarding offer conditions" (INEP, 2015). The CPC is related to the Enade Evaluation Cycle, referring to the triennial results of student performance and aids the renewal of knowledge in undergraduate courses.

The data from the Higher Education Census is updated and conducted by the INEP. It contains information on the HEI that offer undergraduate and sequential courses with specific qualifications, as well as their students and teaching staff. It also includes information on the HEI, their regular or distance learning degrees, sequential courses, places offered, enrolments, freshmen and graduates, and information on the teaching staff in the different forms of academic organization and administrative category (INEP, 2015).

To aid HEI in their planning and management, and in its organizational evaluation process, the MEC provides a model for the drafting of an IDP, with orientation for compliance with its established dimensions, for purposes of accreditation, authorization, and recognition of higher education courses (Dalmagro \& Rausch, 2012). The IDP became a key document due to its centrality and scope as a planning and evaluation tool for HEI:

The reaccreditation of universities and university centers should be centered on the evaluation of the Institutional Development Plan (IDP) of each institution and the current institutional evaluation criteria, promoting a balance between objective and subjective criteria for the evaluation of quality, considering the agility of the process, progressiveness of the set goals and effective and efficient constructive analysis of institutional performance over a certain time (Brasil, 2007).

A HEI is accredited or denied accreditation based on very objective and quantitative criteria. This type of accreditation facilitates the comparisons of HEI, which may be viewed as an advantage in this process. On the other hand, it leaves no space to consider particular details and specific features of organizations. This is one of the weaknesses of the process (Dias Sobrinho, 2008a). Nevertheless, the results of the evaluation seek to promote a continuous improvement process of HEI performance, and serves as a tool for the strategic planning of permanent quality improvement and the pertinence of developed activities.

Frauches (2008) highlights that the objectives of the decree focus on standardizing the exercise of organizational functions and integrating actions in keeping with the evaluation system, the 
SINAES. This enabled better integration between undergraduate courses and the operations of HEI in the federal system, as well as designating the capabilities of the diverse agents involved in processes between HEI and the MEC.

This law has a series of fundamental requirements in order to obtain good results through the "Directives for the evaluation of HEI" and the "Organizational evaluation script". However, it should be emphasized that the HEI can decide to use or not use the suggested structure and they can alter or incorporate other dimensions, demonstrating that these alterations must take autonomous forms of assessment into account, respecting the unique nature of each HEI. According to Mizael et al. (2012), while the law leaves institutions free to draft and formulate their IDPs, it also sets criteria and requirements that curtail the creative capability of HEI.

In this context, the complexity of universities should be highlighted. They are organizations with peculiar and unique characteristics as compared to the vast majority of organizations in society, because of both their environment and function within the contemporary context of knowledge. Among their actions, they play a social role, allowing greater access to knowledge (Cohen \& March, 1974; Baldridge, 1983; Millet, 1962; Weick, 1976).

Organizations can be understood as complex and ambiguous systems surrounded by paradoxes, characteristics that are found wherever there is a network of human interactions. Their systems very often go beyond a rational, linear, and predictable logic, which directly affects their managerial capacity. It happens that, in our society, some organizations tend to be even more complex than others, including churches, hospitals, artistic organizations, and NGOs (Jarzabkowski \& Felton, 2006). Universities are another good example, as they have characteristics such as "diverse fields of knowledge, with a wide range of courses at several levels. Decisions are normally collegiate and political, with qualified and specialized professionals forming distinct interest groups" (Meyer Jr. \& Mangolim, 2006, p. 7). Other previous studies (Baldridge, 1983; Cohen \& March, 1974; Weick, 1983; Millet, 1962) have already identified universities as atypical and paradoxical complex organizations. They have ambiguous goals and are centered on the work of professionals, based on problematic technology, and working with a product that is difficult to measure. Their decision-making processes, and forms of management, mix bureaucratic, political, collegiate and anarchistic aspects, and they exist in a vulnerable environment.

Regarding the "ambiguous institutional goals", some authors (Lanzillotti, 1997; Kast \& Rosenzweig, 1987; Araujo, 1996; Rodriguez, 1983) agree on one aspect, affirming that the goals of universities are not clear or well defined, and because of their ambiguity and inaccuracy, their institutional goals tend to have different "readings". This creates confusion regarding how these goals should be achieved. The lack of shared vision resulting from ambiguity is another aspect that hinders the establishment of operational goals and the development of planning systems, especially for managers when they face the necessity to need and/or quantify these goals.

With regard to being "centered on the work of professionals", authors (Goulart \& Cunha, 1999; Barbosa, 1996; Dussault, 1992; Baldridge, 1983; Kast \& Rosenzweig, 1987) describe how key activities and operational tasks are performed by professionals who have a high degree of autonomy over their own activities. Their skills are gained independent of the organization, and they are "legitimized" outside of their structure, thus weakening the link between professional and organization. Mintzberg (1991, p. 203) highlights that they are the only place in the world where you can act as if you were a freelance worker and at the same time receive a regular salary. These organizations are apparently inside out in that the workers sometimes appear to manage the bosses. Therefore, it is understood that the decision-making power regarding their activities 
is highly personal and that the capacity for control of one part of the organization becomes very limited, unlike other organizations where the power is in the form of a hierarchy.

Concerning "problematic technology", Schwartzman (1996) notes that in universities, for a long time, the technology used did not extend beyond a blackboard and chalk. However, over time, other structures like laboratories, complex equipment, broadly extended campus administration, catering services, student transport and large computer systems were incorporated. In terms of management, universities depend on different collective decision systems that are not very compatible with their complexity. Decisions are slow, managers do not have the legitimacy to make decisions, and the short-term logic of interest groups hinders the development of technologies that could be characterized as rational and efficient (Schwartzman, 1996). On the other hand, universities are "projected" to meet the needs of their students, who are involved in a "productive process". Therefore, their technology is directly applied to human beings, which also hinders, or impedes, the rationalization or standardization of processes. This type of service provided to students implies another problem: what kind of technology and staff does the organization need to conduct its multidisciplinary work? (Baldridge, 1982, p. 26).

Another important aspect is derived from "problematic technology": the complex process of "evaluating the quality of higher education". This is usually not a consensual issue, as there is no distinction between evaluation experiences and regulation (Souza, 2017; Dias Sobrinho, 2008b; Marchelli, 2007). "To accredit is to certify quality. But what does quality actually mean? Which quality, who defines it and for whom?" (Dias Sobrinho, 2008b). According to the author, the answer to these questions lies in two antagonistic "worldviews" concerning higher education. One approach to quality is from the social viewpoint, which values aspects that enable ethical qualification and the intellectual development of individuals, and understanding education as a public good. The second approach is quality associated with the market, considering education as a good whose value lies in the development of competencies for work, accrediting individuals for employment. Harvey and Williams (2010), in their studies, claim that the international literature focuses more on themes related to evaluation or regulation processes and/or productions specifically focused on quality parameters and indicators. Souza (2017) complements this by stating, "faced with the various possibilities for defining quality, it is understood that its meaning emerges from the interests of those directly affected by it, altering it over time in accordance with the reconfiguration of these interests".

In relation to the "organizational structure", universities also have other singularities: their diverse fields of knowledge (departments) as constituted by different groups of specialists who use their autonomy and expertise to conduct the basic activities of the institution (teaching, research, and extension). They are "non-integrated organizations. They usually consist of three different levels, with professors occupying the most important positions in the hierarchy: (1) top management, which is made up of the dean, assistant deans and their aides; (2) academic management, including the heads of faculties, centers, departments, institutes, etc.; and (3) directors of administrative activities, wherein lie the auxiliary services, such as human resources, finance, purchasing and other general services. Because of these particularities, university organizations are characterized as having a decentralized structure, since the power is not concentrated in the hands of the top management (Vught, 1988; Kast \& Rosenzweig, 1987; Maassen \& Potman, 1990; Mintzberg, 1991).

In universities, the authority and, consequently, the "decision-making” power emerges through obtained knowledge. However, the power that stems from those who have knowledge in universities 
BBR

17

72

is greatly dispersed, especially because of teachers and researchers. Nevertheless, there is a set of decisions that are not influenced, let alone submitted to this power, such as financial administration and other support services.

Corroborating the characteristics of universities and their implications for their management, Meyer and Lopes (2003) highlight the need to examine their rational, political and symbolic dimensions to understand better the complexity of planning in universities. According to the authors, the rational dimension highlights the efforts of managers to order, in a logical and rational manner, the goals, decisions, and use of scarce resources in the actions involved in seeking the desired outcomes. The political dimension highlights the importance of planning through a negotiation process between interest groups, on whose support the planning depends. The third, symbolic, dimension highlights planning as a symbol, with this being the most important aspect of planning. The authors explain that, "In practice, these dimensions are mixed to form a complicated combination of approaches, reflecting one of the main difficulties faced by university managers, the planning of such a complex, ambiguous, paradoxical and conflicting, and therefore challenging, organization". It is perceived that universities, unlike structured mechanistic organizations based on rational models, are either loosely coupled (Orton \& Weick, 1990) or organized anarchies (Cohen \& March, 1974), thus constituting a differentiating factor for this group of organizations. "The fact that their agents share few points in common and at the same time maintain their independence and autonomy has clear implications for the performance of these organizations and how they are managed" (Meyer Jr., Pascucci, \& Mangolin, 2012).

Andrade (2002) warns that these characteristics tend to hinder "tools" managed in other business environments from being fully used in this context. Therefore, universities require an approach with different management models or criteria from other organizations, both in the public and private sector.

Therefore, because of their sui generis characteristics, it is opportune to consider these aspects so that it is feasible to follow procedures that suit this reality. Due to a misunderstanding of the nature and complexity of the workings of a university, whatever the approach, there tends to be a risk of there not being any value for them (Castor \& Suga, 1988; Mintzberg \& Quinn, 2001; Meyer Jr., 2005). To perform such a strategic role in society, considering their responsibility with their assets and their response to the concerns of the community in general, they cannot be left in the background. On the contrary, "there is no other organization with so much responsibility in the effective use of management models than the one that creates, theorizes, produces and reproduces these models" (Elpo, 2004, p. 2).

\section{CONCEPTUAL MODEL AND PROPOSITIONS}

\subsection{ISOMORPHIC PRESSURES AND THE IDP}

HEI are embedded in a dynamic context, one which is ravaged by transformation and changes. These organizations are essentially service providers, and are not exempt from the effects of the market in which they operate on the other sectors of the economy. These factors tend to lead them to recognize the importance of rethinking their management, allowing them to seek a more competitive and continuous managerial view, promoting a strategic adaptation process.

There are numerous expectations regarding HEI, not only due to the significant contributions that higher education can make to society, but also their ability to react to challenges. These include ambiguous goals, centered around the work of professionals, based on problematic technology, 
operating a product that is difficult to measure, and living with a decision-making process and forms of management that combine bureaucratic, political, collegial, and anarchistic aspects (Baldridge, 1983; Cohen \& March, 1974; Weick, 1983). These characteristics become obstacles to the quality of management, often thwarting initiatives or actions that build a more effective process of strategic organizational adaptation (Torres \& Guimarães, 2008; Lobo \& Silva Filho, 2010). Organizational adaptation involves various elements, not only of the organization but also the environment, being influenced by internal and external coalitions (Mintzberg, 1983). Therefore, the results emerge not only as a product of rational debates, but also as ones shaped by interests and commitments of individuals and groups, bureaucratic forces, major changes in the environment, and the manipulation of the structural context (Pettigrew, 1979).

In this respect, Institutional Theory has helped to provide a better understanding of organizational phenomena, especially concerning the reaction of organizations to pressures from their context. These pressures may be rooted in the regulation of the State, competition and professional categories, leading organizations to become similar or homogeneous through isomorphic mechanisms (Meyer \& Rowan, 1977).

Therefore, the initial proposition of institutional theory emerges as a stance against more rationalist models that involved technical, productive, and managerial processes, and now have in their approach the elements of cultural systems, relationships, structure, and the actions of organizations. In other words, institutional theory assumes that organizations and environment are symbolic entities, according to DiMaggio and Powell (1991) and March and Olsen (1976).

Understanding what constitutes an "organizational field" is a key element, viewing it as organizations that jointly constitute a recognized field of institutional life, such as suppliers, consumers, regulatory agencies, and other organizations that produce similar products/services. Organizational fields in their early stages could be described as being highly diversified, and as they are structured and established, they become increasingly homogeneous (DiMaggio \& Powell, 1983).

The concept of institutional isomorphism is related to processes through which institutions from the same "organizational field" tend to converge towards similarity through their structures and by adopting similar strategies and processes (Scott, 2001).

Meyer and Rowan (1977) were the first authors to use this definition, demonstrating that this phenomenon induces organizations to "understand" that practicing an already achieved action becomes a "guarantee" against possible reprehensible behavior. Under these circumstances, the legitimacy of the organization comes into play, i.e., through isomorphic behavior, the organization is recognized as having values and behavior coherent with the values and expectations of social actors.

With more in-depth studies on isomorphism, a sub-classification emerged, the competitive and the institutional. The former was a result of the competition that existed between the institutions that compose a certain market. Meanwhile, institutional isomorphism, according to Hawley (1968), is a process of restriction that induces a unit of a population to become more similar to other units that face the same set of environmental conditions.

The purpose of companies is not just to dispute resources and customers. Underlying issues such as political power and institutional legitimacy, through social adaptation, as well as economic adaptation, are also factors that interest them. Therefore, the concept of institutional isomorphism is important when it comes to understanding the political and ceremonial aspects that permeate a considerable part of modern organizational life (DiMaggio \& Powell, 1983). Thus, the strategies 
BBR

17

74

adopted by the organization can be viewed as consequences of institutionalized patterns in the organizational environment. These patterns can be influenced by coercive, normative and mimetic isomorphic mechanisms (DiMaggio \& Powell, 1991).

Coercive isomorphism is the result of formal and informal pressures from other organizations as a form of persuasion to adapt to patterns. Mimetic isomorphism is an imitation, copying established models and often bowing to pressure from consumers and employees. Normative pressure is a model of isomorphism often found in professionalization, with employees acting in a similar way and through strong socialization in the workplace (DiMaggio \& Powell, 1983).

It is understood that HEI can modify their structure, academic practices, and behavior as a result of homogenization, i.e., isomorphism, which can be used to explain barriers against diversity, receptivity and improvement in higher education. Chan (2016) highlights that the concept of isomorphism is important when it comes to understanding how institutional environments affect organizational structures, the flow of resources for higher education, and how they conform to the similar cultural norms and values of HEI in response to environmental uncertainty, unclear technology, and/or ambiguous goals. Isomorphism is also useful when it comes to understanding the relationship between organizations and academic environments, and in understanding how educational organizations adopt similar symbolic elements instead of reacting rationally to competitive external markets and social expectations (Hoy \& Miskel, 2008).

Chan (2016) claims that HEI normally become involved in activities of homogenization because they face fierce competition from one another to conform to the social rules and cultural pressures of individuals and others. Cai (2009) found that institutional isomorphic mechanisms were at play in a single organization, confirming the susceptibility of HEI to global isomorphic pressures in their decision-making processes when it comes to the transformation of governance models in higher education. This may also occur because the presidents and members of boards of directors are involved in similar activities, practices, and behaviors among constituents in order to achieve organizational success and survival in higher education (Miller-Millesen, 2003).

Understanding institutionalization as a process of sedimentation, homogenization and legitimacy, from the context analyzed in the Brazilian higher education system following the LDB in 1996, it may be supposed that HEI are being induced to the process of institutional isomorphism. Diniz et al. (2015) presented some indices to reinforce this line of reasoning: the strict regulation that promoted an intense discussion on higher education; the numerous newcomers that would be established in accordance with current legislation; curricular directives that limited the differentiation of undergraduate courses due to "curricular minimums"; the evaluations and classifications promoted by the MEC; and plans and quality indicators (National Student Performance Examination (Enade), General Course Index (IGC), Preliminary Course Concept (CPC)) applied to HEI.

In this study, two possible influences will be examined through Propositions P1 and P2. In Figure 1, Situation A, an overview is provided of the elements that constitute the institutional environment of the Brazilian higher education sector and the pressures suffered by HEI and their response in terms of isomorphic adaptation mechanisms.

P1 - As universities come under isomorphic pressures, their IDPs are not presented as strategic documents. Therefore, they seek to meet legal requirements to gain legitimacy. 


\subsection{Resource-BASEd View (RBV)}

Although there is no single and exclusive theory for the creation of business strategies, organizations use instruments and mechanisms to formulate and manage their strategic assets. Therefore, explaining and understanding strategy and sources of sustainable competitive advantages are a concern of executives and entrepreneurs (Serra, Ferreira, Pereira, \& Lissoni, 2008). Thus, the use of the RBV in different organizational contexts has been one of several alternatives (Competitiveness Theories, Institutional Theory and Contingency Theory) used for a fuller understanding of how the combination of resources can help to develop sustainable competitive advantages in a strategic group. A strategic group is understood here as a set of companies that operate in the same sector at the same time and have similar profiles, characteristics, products, and services (Fiegenbaum \& Thomas, 1993).

The approach of the RBV, unlike the determinist view of the industrial organization, is mainly focused on using internal resources as the principal determiners of competitiveness (Prahalad \& Hamel, 1990; Wernerfelt, 1984).

Therefore, it may be understood that the RBV is a theory that seeks to help organizations to evaluate their internal environment, particularly their resources and capabilities, gauging how these can help to create competitive advantages (Barney \& Hesterly, 2011).

Although the theme is considered a recent one, the RBV originated in the works of Chamberlin (1933) and Robinson (1933) (Fahy, 2000). It evolved with Penrose (1959), who claimed that a company has a competitive differential due to the heterogeneity of productive resources. Later, Barney (1991) contributed to the theory, claiming that the superior performance of organizations is due to their resources, competencies and individuality, which can be inimitable, non-transferable and non-substitutable. Finally, Hamel and Prahalad (1995), understand that an organization can be viewed not only as a portfolio of products and services, but also as a portfolio of competencies, claiming that essential competencies emerge from collective learning, mainly concerning the coordination of various production skills and the integration of multiple technologies.

Therefore, the formulation of strategies, according to the RBV, should be based on the combination that uses company resources the most efficiently and accumulates them in order to improve performance. Thus, it creates possibilities to analyze the company's position in terms of the resources it uses and, from this assessment, to propose options for the strategies to be adopted (Wernerfelt, 1984; Mintzberg \& Rose, 2007; Hoopes, Madsen, \& Walker, 2003).

Junges (2010) highlights that, although the RBV strives to construct its assumptions in a dynamic and contemporary context, identifying and developing internal resources from this perspective is not easy. The knowledge of the organization and capability to create exclusive knowledge, therefore, should be the focus of organizations in the development of their strategies.

To explain why two companies operating in the same strategic group have different results, Barney and Hesterly (2009) used two premises regarding the resources and capabilities that organizations have under their control: heterogeneity of the immobility of resources, and capabilities. The heterogeneity of resources means that, in a certain line of business, some organizations can be more competent at certain activities than others (Barney \& Hesterly, 2009). Regarding capabilities, these have to do with the time in which these differences between resources and capabilities can be sustained by organizations, i.e., it may be very costly for companies, without certain resources and capabilities, to develop or acquire them. The authors also claim that resources can be classified as financial, physical, human and organizational, highlighting that they can be partly tangible 
and intangible. In the literature, the usual names can be found, including physical, human, and organizational assets or assets of inventory, skills, and capabilities (Nieto \& Perez, 2002).

There are also dichotomous divisions, such as those proposed by Miller and Shamsie (1996): property-based resources and knowledge-based resources, which include both intangible assets and capability simultaneously. In general, tangible, physical and property-based resources tend to be easily subjected to accounting or inventory. They include equipment, stock, plants, and earth deposits. They are easy to copy and are sources of competitive advantage only if there are exclusive rights to or control over them, thus creating barriers against competitors (Fahy, 2000).

Intangible resources are related to reputation, patents, relationships, and more complex and specific intellectual skills. This means they are difficult to measure and copy (Thompson \& Cole, 1997). Finally, capabilities are interactions of resources, collective knowledge, coordination, and the integration of technical, creative, and collaborative skills. These capabilities are identified by Prahalad and Hamel (1990) as essential capabilities that promote competitive differentials for organizations. As these assets are interactive and involve a set of complementary resources, it is understood that they are more difficult to imitate and measure.

As HEI belongs to a strategic group and are defined as complex organizations and thus very different from a typical business organization, their behavior nowadays gives rise to strategic business administration (Mintzberg \& Rose, 2007), compelling them to develop innovative competitive strategies to attract, win over, and maintain customers to remain in the market or increase their market share.

Market-oriented HEIs tend to deliver to their customers, students and society, competencies that will make a difference in a worker's performance. These competencies are derived from the internal abilities and resources of each HEI, and their competitive advantage is found in the professional that enters the job market, thus constructing a strong image in the eyes of society (Mazzarol \& Soutar, 1999). Therefore, it is understood that a HEI needs to evaluate carefully the challenges and threats that stem from the environment, identifying the needs of stakeholders, attracting and consolidating resources, facing external changes and solving internal problems (Mainardes et al., 2009). This is because the ability of an HEI to react to environmental changes, meet the needs of its target public, and resolve internal problems determines its competitive behavior.

The RBV is a theory that seeks to help organizations evaluate their internal environment, gauging how their resources and capabilities can help to create competitive advantages (Barney $\&$ Hesterly, 2009). Therefore, its use in the context of higher education can help to understand, develop, and enact strategies, as the theory assumes that the entire organization is a set of unique capabilities and resources that can generate the basis of its strategy and be the main source of its profits (Hitt, Ireland, \& Hoskisson, 2003).

Providing better quality services by acquiring and developing human resources (Srivastava, Fahey, \& Christensen, 2001), for example, follows this path. Christiano, Gohr and Gomes (2016) found that the knowledge in the institution, although not fully used, could be considered a strategic resource and source of competitive advantage. Understanding that changes in social systems can generate structural disadvantages, thereby heightening competition between HEIs. Ho and Peng (2016) pointed out the need for HEI managers to understand how to improve performance through relationships between institutional resources and social capital. Therefore, managers of HEI can use strategies to learn from others, whether competitors or not, thus improving the use of their resources and capabilities (Voss, Blackmon, Chase, Rose, \& Roth, 1997). This will 
lead to more consistent growth and sustainability, with a more businesslike profile or as a social entity (Samonetto \& Campos, 2013).

Understanding that because of the changes to the regulatory framework as a result of the

$\mathrm{LDB} / 96$, the higher education sector underwent significant changes that forced HEI to make better use of their resources and capabilities, making them more competitive.

In Figure 1, Situation B, the elements that constitute the institutional environment of the Brazilian higher education sector and the pressures suffered by HEI and their response are generally illustrated in terms of making them more competitive by using their resources and capabilities.

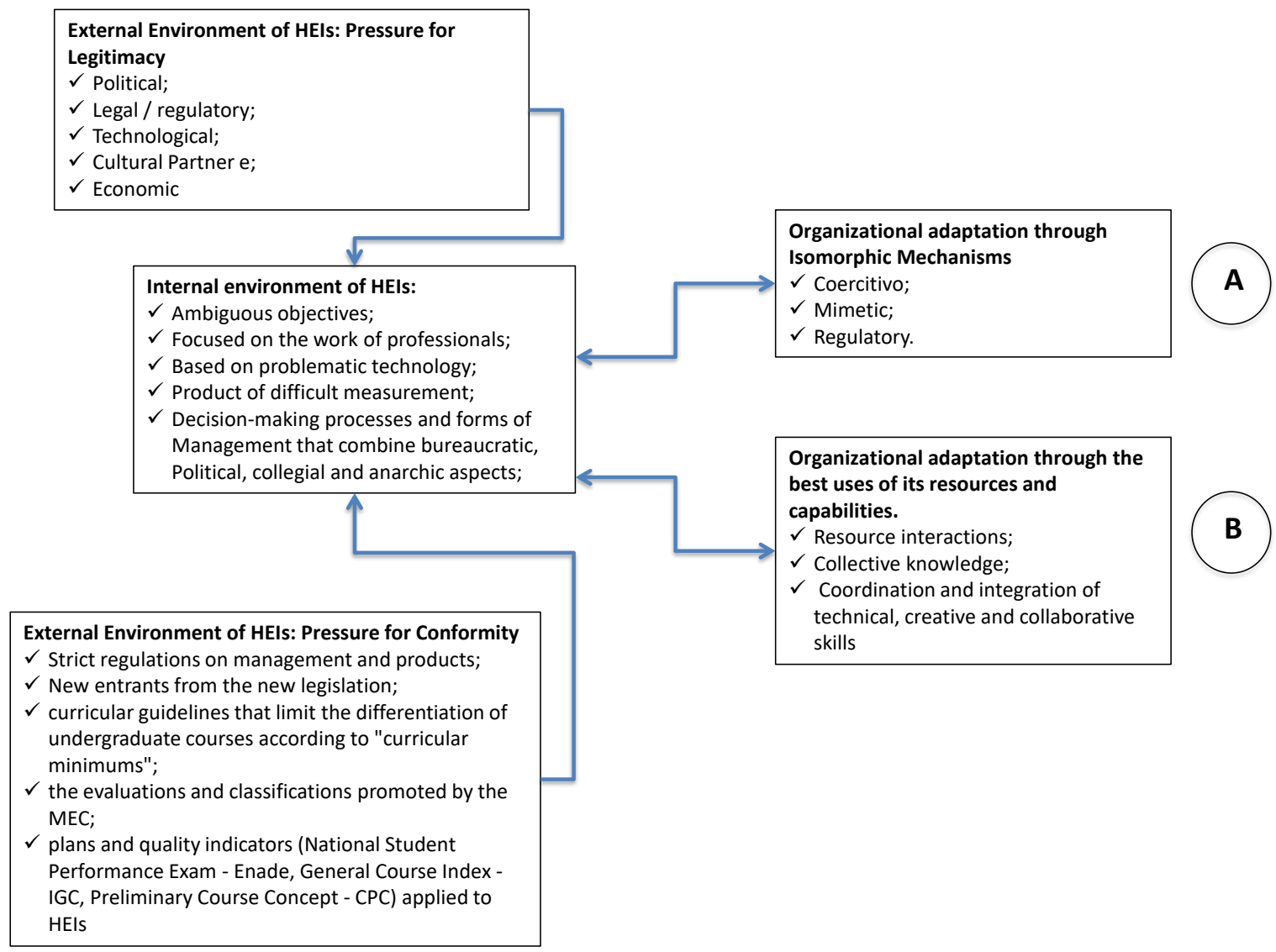

Figure 1. Generic model of the interaction of HEI and the Institutional Environment of higher education in Brazil.

Source: Prepared by the authors.

P2: Despite suffering isomorphic pressures, universities tend to consolidate their strategic actions, as expressed in their IDPs, to portray singularly the use of their institutional resources and capabilities. 


\section{METHODOLOGICAL PROCEDURE}

17

\subsection{SAMPLE OF IDPS}

To define the HEI and the IDPs that would constitute the sample, an effort was made to understand how the "universe" of HEIs in Brazil are structured. In this case, the pertinent legislation was consulted, in which HEIs are classified as Universities and Non-Universities. University organizations are divided into universities, specialized universities, and university centers. The group of universities can be further broken down into public (federal, state or municipal), for-profit private universities, or non-profit private universities (community, confessional or philanthropic) (Mondine \& Domingues, 2005).

The second step was to define the type of academic organization to work with, and, for this criterion, it was decided to use universities. According to the MEC, universities are multidisciplinary organizations. They can be public or private and their aim is to qualify professionals with high levels of education, regularly developing teaching, research and extension activities.

As a result of this choice, there was also a need to use subcategories of universities established by Brazilian legislation (public, private for-profit, and private non-profit). They are private forprofit in a narrow sense when they are instituted and maintained by one or more people or private companies. They are private non-profit when they have a social vocation, i.e., community when created by groups of individuals or one or more companies, including cooperatives of students and teachers that include representatives of the community in the university, and confessional when constituted by confessional or ideological motivations. Public universities are created (by a bill of law proposed by the executive branch and approved by the legislative branch of power) or incorporated, maintained, and managed by the public authorities. The use of this sub-classification was necessary because, in addition to legal devices, other specific features of universities, such as cultural, regional and vocational aspects, affect the distribution of responsibilities, competencies, resources and technologies. These aspects affect their operations alongside the community and society in general.

The final criterion established to compose the sample was directly related to the universities themselves, i.e., how to define a choice between one university and another. To this end, the Folha University Ranking (RUF) was used. This is an annual assessment of higher education that has been published in Brazil since 2012. In the RUF, the 195 Brazilian private and public universities are classified using five indicators: research, internationalization, innovation, teaching, and market. The data that composes the RUF evaluation indicators are collected from the Higher Education Census of the Inep-MEC, Enade, SciELO, Web of Science, Inpi, Capes, and CNPq, as well as state foundations for science research and two annual surveys conducted by Datafolha.

Regarding the "Quality of Teaching" indicator, three quantitative components are considered: proportion of masters and doctors in total teaching staff, proportion of partially and fully dedicated professors, and student performance based on the ENADE grade, as well as Datafolha research based on 2,125 interviews conducted between 2014 and 2016 with qualified teaching staff as MEC assessors. The "Work Market" indicator is based on 5,975 interviews conducted by Datafolha from 2014 to 2016 with professionals from companies, hospitals, doctor's surgeries, schools and others.

The "Internationalization" indicator considers, in two components, the international citations received by academic works from Brazilian universities in 2014 and the share of publications with international co-authorship in the total of academic articles published in 2012 and 2013. 
"Scientific Research" seeks to evaluate the excellence of scientific research by universities using seven components, including number of scientific works published in 2012 and 2013, number of citations of scientific articles in 2014, and resources captured by universities from federal and state agencies that promote science in 2014. Finally, the "Innovation" indicator considers requests for patents from universities from 2005 to 2014 (Folha de São Paulo, 2016).

This ranking was chosen because the scope of its evaluation is understood to be broader based on the indicators outlined above. Its methodology is based on common indicators from consolidated national and international rankings (U.S. News (USA), MacLean (Canada), The Guardian (United Kingdom), Die Zeit (Germany), Reforma (Mexico), and Americaeconomia (Chile)), and it has indicators that evaluate the local scenario. The results of the ENADE are also incorporated into the methodology through the "Teaching Indicator", and the data are collected from national and international databases such as the INEP-MEC, SciELo, Inpi (patents) and Thomsom Reuters. These elements characterize the essential functions of a university (Folha de São Paulo, 2016).

The data that make up the evaluation indicators of the RUF are collected from Brazilian patent databases, scientific journal databases, MEC bases, and national opinion polls conducted by Datafolha (Folha de São Paulo, 2016). For each quadrant, the first five universities that made their IDP available online in compliance with current legislation were selected.

Chart 1 shows the distribution of the IDPs of the universities selected according to the aforementioned criteria. It should be highlighted that the upper quadrants contain the universities with strong corporate orientation or are part of an academic oligarchy. The universities in the lower quadrants have a strong identity-based appeal, despite the academic oligarchy and pressures.

Chart 1

Distribution of IDPs by quadrant

\begin{tabular}{lll}
\hline & Public State or Federal University & $\begin{array}{l}\text { Private University belonging } \\
\text { to a large group }\end{array}$ \\
\cline { 2 - 3 } $\begin{array}{l}\text { University with strong corporate } \\
\text { orientation or from the academic } \\
\text { oligarchy }\end{array}$ & $\begin{array}{l}\text { Federal University A } \\
\text { Federal University B }\end{array}$ & $\begin{array}{l}\text { Private University A } \\
\text { Pederal University C }\end{array}$ \\
& Federal University D & Private University C \\
& Federal University E & Private University D \\
& Confessional University & Private University E \\
\cline { 2 - 3 } Strong identity appeal despite the & Pontifical Catholic University A & Community University \\
academic oligarchy and pressures & Catholic University B & Community University A \\
& Presbyterian University C & Community University C \\
& Catholic University D & Community University D \\
& Pontifical Catholic University E & Community University E
\end{tabular}

Source: Prepared by the authors. 


\subsection{Data Collection and Analysis Procedures}

To analyze the IDPs, content analysis was used, which may be defined as a set of methodological instruments, which undergo constant improvement, to analyze different sources of content, both verbal and non-verbal. According to Bardin (2009), content analysis consists of various communication analysis techniques that seek to achieve systematic results to produce inferences. In this sense, $\mathrm{Nvivo}^{\oplus}$ was used to aid the data analysis in three stages, as shown in Figure 2.

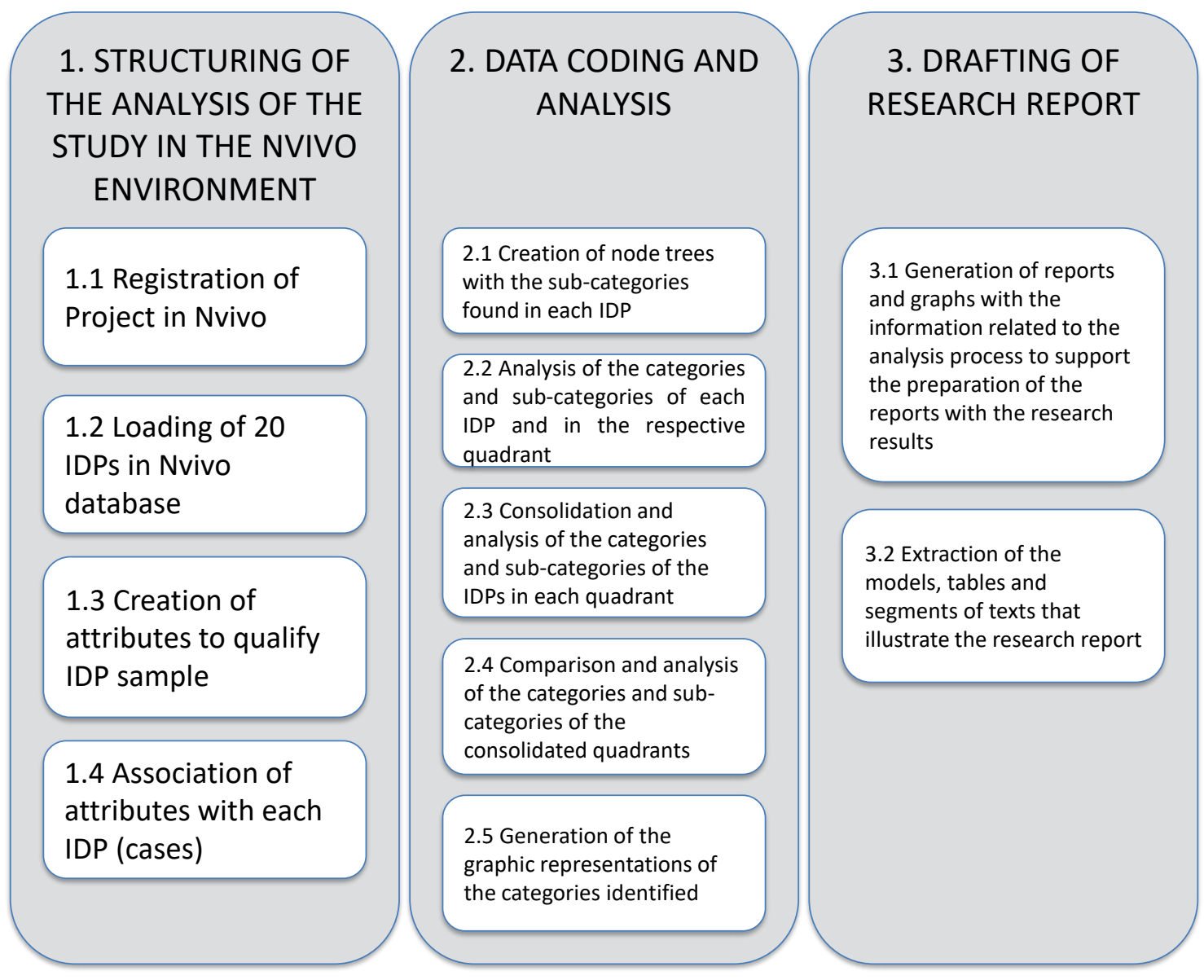

Figure 2. Phases of the data analysis process of the study.

Source: Adapted from Lage (2011).

In Phase 2, a total of 695 coded segments were identified based on the reading of 20 IDPs $(2,668$ pages). This coding was done by clustering each of the 695 segments under a primary code that generically reflected the segmented content. In this phase, 44 primary codes were identified. Later, one by one, the codes were linked according to their characteristics, and another six intermediary codes were identified: organizational profile, organizational management, financial and budgetary aspects, academic organization, infrastructure, evaluation and organizational monitoring. These six intermediary codes were linked to another two final categories (Chart 2). 
Chart 2

Matrix of research codes

\begin{tabular}{|c|c|c|c|c|}
\hline Order & $\begin{array}{l}\text { Coded } \\
\text { Segments }\end{array}$ & Initial Categories & $\begin{array}{l}\text { Intermediate } \\
\text { Categories }\end{array}$ & Final Categories \\
\hline 1 & 20 & Historical (Summary) & \multirow{9}{*}{$\begin{array}{l}\text { I. Organizational } \\
\text { Profile }\end{array}$} & \multirow{25}{*}{$\begin{array}{l}\text { I. Organizational } \\
\text { Mission, } \\
\text { Management and } \\
\text { Investments }\end{array}$} \\
\hline 2 & 11 & Regional Inclusion & & \\
\hline 3 & 16 & Mission & & \\
\hline 4 & 16 & Purposes & & \\
\hline 5 & 57 & Objectives and Goals & & \\
\hline 6 & 17 & Area of Academic Operations & & \\
\hline 7 & 27 & Social Responsibility & & \\
\hline 8 & 33 & Teaching Policies & & \\
\hline 9 & 58 & Extension and research policies & & \\
\hline 10 & 3 & $\begin{array}{l}\text { Organizational structure, decision-making } \\
\text { and institutional and academic } \\
\text { organization chart }\end{array}$ & \multirow{13}{*}{$\begin{array}{l}\text { II. Organizational } \\
\text { Management }\end{array}$} & \\
\hline 11 & 4 & $\begin{array}{l}\text { Collegiate bodies: attributes, } \\
\text { competencies and composition }\end{array}$ & & \\
\hline 12 & 5 & Support bodies for academic activities & & \\
\hline 13 & 4 & $\begin{array}{l}\text { Autonomy of HEI in relation } \\
\text { to the maintainer }\end{array}$ & & \\
\hline 14 & 14 & $\begin{array}{l}\text { Relationships and partnerships with the } \\
\text { community, institution and companies }\end{array}$ & & \\
\hline 15 & 20 & $\begin{array}{l}\text { Teaching staff (composition, qualification } \\
\text { policies, career plan and work regime }\end{array}$ & & \\
\hline 16 & 6 & $\begin{array}{l}\text { Expansion schedule and plan for the } \\
\text { teaching staff, with titles and work regime, } \\
\text { with details of existing profile for the } \\
\text { duratio of the IDP }\end{array}$ & & \\
\hline 17 & 14 & $\begin{array}{l}\text { Technical/administrative staff } \\
\text { (structuring, qualification policies, } \\
\text { career plan and/or positions and salaries } \\
\text { and expansion schedule }\end{array}$ & & \\
\hline 18 & 20 & $\begin{array}{l}\text { Forms of access, financial programs } \\
\text { for pedagogical support (scholarships) }\end{array}$ & & \\
\hline 19 & 24 & $\begin{array}{l}\text { Stimuli to remain (leveling program, } \\
\text { psycho-pedagogical services) }\end{array}$ & & \\
\hline 20 & 2 & $\begin{array}{l}\text { Student organization (space for students } \\
\text { to participte and interact) }\end{array}$ & & \\
\hline 21 & 7 & Monitoring of graduates & & \\
\hline 22 & 12 & Graduate profile & & \\
\hline 23 & 8 & $\begin{array}{l}\text { Economic and financial } \\
\text { management strategies }\end{array}$ & \multirow{3}{*}{$\begin{array}{l}\text { III. Financial and } \\
\text { Budgetary Aspects }\end{array}$} & \\
\hline 24 & 2 & Investment plans & & \\
\hline 25 & 1 & Five-year budgeting and schedule & & \\
\hline
\end{tabular}


BBR

17

82

\begin{tabular}{|c|c|c|c|c|}
\hline Order & $\begin{array}{l}\text { Coded } \\
\text { Segments }\end{array}$ & Initial Categories & $\begin{array}{l}\text { Intermediate } \\
\text { Categories }\end{array}$ & Final Categories \\
\hline 26 & 1 & Content selection & \multirow{14}{*}{$\begin{array}{l}\text { VI. Academic } \\
\text { Organization }\end{array}$} & \multirow{21}{*}{$\begin{array}{l}\text { II. Academic } \\
\text { Organization, } \\
\text { Evaluation } \\
\text { and Academic } \\
\text { Installations }\end{array}$} \\
\hline 27 & 9 & Methodological principles & & \\
\hline 28 & 10 & Evaluation process & & \\
\hline 29 & 15 & Innovative teaching practices & & \\
\hline 30 & 18 & $\begin{array}{l}\text { Internship policies, professional practice } \\
\text { and complementary activities }\end{array}$ & & \\
\hline 31 & 30 & Distance learning policies and practices & & \\
\hline 32 & 11 & $\begin{array}{l}\text { Inclusive education policies } \\
\text { (people with special needs) }\end{array}$ & & \\
\hline 33 & 23 & Offer of undergraduate courses & & \\
\hline 34 & 19 & Offer of sequential courses & & \\
\hline 35 & 15 & Offer of special teacher training programs & & \\
\hline 36 & 19 & Offer of postgraduate courses (latu sensu) & & \\
\hline 37 & 23 & Offer of postgraduate courses (stricto sensu) & & \\
\hline 38 & 10 & Extension programs & & \\
\hline 39 & 15 & Research programs & & \\
\hline 40 & 3 & Physical infrastructure & \multirow{5}{*}{ V. Infrastructure } & \\
\hline 41 & 3 & Academic infrastructure & & \\
\hline 42 & 5 & $\begin{array}{l}\text { Adaptation of infrastructure to suit } \\
\text { people with special needs }\end{array}$ & & \\
\hline 43 & 18 & $\begin{array}{l}\text { Strategies and means of internal } \\
\text { and external communication }\end{array}$ & & \\
\hline 44 & 5 & $\begin{array}{l}\text { Schedule for expanding the infrastructure } \\
\text { for the period of validity of the IDP }\end{array}$ & & \\
\hline 45 & 29 & $\begin{array}{l}\text { Project for the evaluation and monitoring } \\
\text { of academic teaching, research, expansion, } \\
\text { planning and management ativities }\end{array}$ & \multirow{2}{*}{$\begin{array}{l}\text { VI. Evaluation and } \\
\text { Organizational } \\
\text { Monitoring }\end{array}$} & \\
\hline 46 & 13 & Ways of using the results of evaluations & & \\
\hline
\end{tabular}

Source: Prepared by the authors. 


\section{RESULTS}

The preliminary analysis of the IDPs using ISNER ${ }^{\circ}$ software found that the IDPs of the universities in question contain some characteristics, which to a greater or lesser extent, are common to all, irrespective of the quadrant in which they were classified (Table 1). Another perception was that most of the IDPs are much more descriptive documents, with operational plans and goals, than a document with strategic features. There was a perceived concern over formalization with the goals to be achieved in the timeframe of the document. This suggests that these activities are presented to satisfy a legal requirement and/or because of their "natural" expansion/growth. For example, there are no plans for investments (most do not state any) or any link between the budget and strategic plan. As for issues of research, teaching, and extension, although some details are given, they have more to do with maturity (how long the organization has existed), type of academic organization, and demographic issues than with a planned, deliberate and therefore strategic intention.

Table 1

Terms common to all the IDPs

\begin{tabular}{|c|c|c|c|c|}
\hline & Community & Confessional & Private & Public \\
\hline postgraduate & 787 & 615 & 581 & 399 \\
\hline institutional development & 675 & 97 & 474 & 102 \\
\hline development plan & 640 & 78 & 463 & 96 \\
\hline institutional development plan & 619 & 64 & 458 & 85 \\
\hline undergraduate courses & 265 & 240 & 209 & 113 \\
\hline research and extension & 321 & 120 & 143 & 110 \\
\hline teaching and research & 255 & 128 & 136 & 119 \\
\hline teaching, research and extension & 204 & 109 & 124 & 97 \\
\hline teaching staff & 118 & 137 & 172 & 59 \\
\hline technical and administrative & 88 & 84 & 122 & 35 \\
\hline postgraduate courses & 101 & 65 & 94 & 34 \\
\hline research projects & 68 & 64 & 83 & 23 \\
\hline undergraduate and postgraduate & 77 & 63 & 41 & 42 \\
\hline research groups & 56 & 30 & 45 & 35 \\
\hline
\end{tabular}

Source: Prepared by the authors.

The academic infrastructure presented in most of the IDPs, especially those of the private universities, tends to be the minimum necessary for the universities' activities and to avoid legal sanctions from the regulatory agencies (MEC), such as loss of accreditation. This also occurs with regard to "academic services". Although the MEC only recommends a structure for constructing the IDP, not all of them meet the requirements of the regulatory agency. Universities that have a better structure (public and confessional) tend to follow the script more closely, which is not the case with the others. In their studies, Dalmagro and Rausch (2012) also found that none of the IDPs in their sample of federal universities met $100 \%$ of the requirements and dimensions established by the MEC. Five universities met over $70 \%$, ten met $50 \%$ to $70 \%$, and nine universities complied with fewer than $50 \%$ of the items established by the MEC. 
BBR

17

84

In the older and better-structured universities (generally the public and confessional), it was found that search and/or the "strategy itself" are closer to a pattern that would be considered of "excellence". This means updated and first class infrastructure, availability of adequate resources for research, teaching and extension activities, and ability to attract renowned researchers. It also means curricular structure and teaching methods oriented by multidisciplinary and interdisciplinary intervention, active and routine participation of foreigners as teachers and students, resulting from its stage of maturity rather than a deliberate strategic intention to obtain a "competitive advantage". That this intention is more focused on competitiveness is revealed to a greater degree in the universities in the private and community quadrants. Regarding the IDP, Picchiai (2012) points out that "(...) there is a language that is not very objective and assertive in most IDPs. It seems to be more of a formality to be delivered to the MEC as a requirement to comply with educational demands" (p. 41).

On the other hand, in most of the documents analyzed, the importance and relevance of the process of constructing the IDP as a benefit for the management and university organization as a whole is clear. This consensus may be represented by a statement from one of the universities. "In general, it can be inferred that having an IDP helped the excellence of this university to evolve, and this was positively perceived by the community". Others highlight the importance of the IDP and the SINAES system as an advance and development in the management of universities.

Figure 3 shows two phenomena that deserve to be considered. One shows the importance of IDPs to universities, especially community and private ones, a subject that will be addressed later. The other demonstrates the convergence towards the same term and thus the similarity of "strategic" actions.

Figure 3 shows that the term "Institutional Development Plan" is concomitantly highlighted by private and community universities. This emphasis on the term IDP by these two types of university in their documents can be explained to a certain extent first by the change in the legal framework of higher education in Brazil, and second as a result of the first, the strict regulation of the sector by the state. It can also be explained by the strong "political" movement in community universities.

With an alteration in the legal framework of Brazilian higher education, a third pole emerged in the sector, which now has, according to Oliveira (2002), the following profile: "the state pole, defending all education controlled and provided by the State; the community pole, made up of religious and lay HEI, but which charge fees, defending the right to public but not state education; and the private-business pole, defending the offer of education as a marketable service". Therefore, with the growth of the private/market network of higher education, community universities have suffered with the growing competition for new students. Adding to this context the need to meet the legal requirements, the use of an IDP emerges as a tool that creates a potential for their capabilities and internal resources, making them "more competitive" in economic terms and academic quality. Therefore, it is understood that the IDP has become a tonic for this kind of university.

The use of Nvivo revealed that the textual content could be presented under two macrodimensions: Organizational Mission, Management and Investments, and Academic Organization, Evaluation and Academic Installations. The intention was to obtain two dimensions that could handle questions related to the activities of means and support and end activities of universities. 


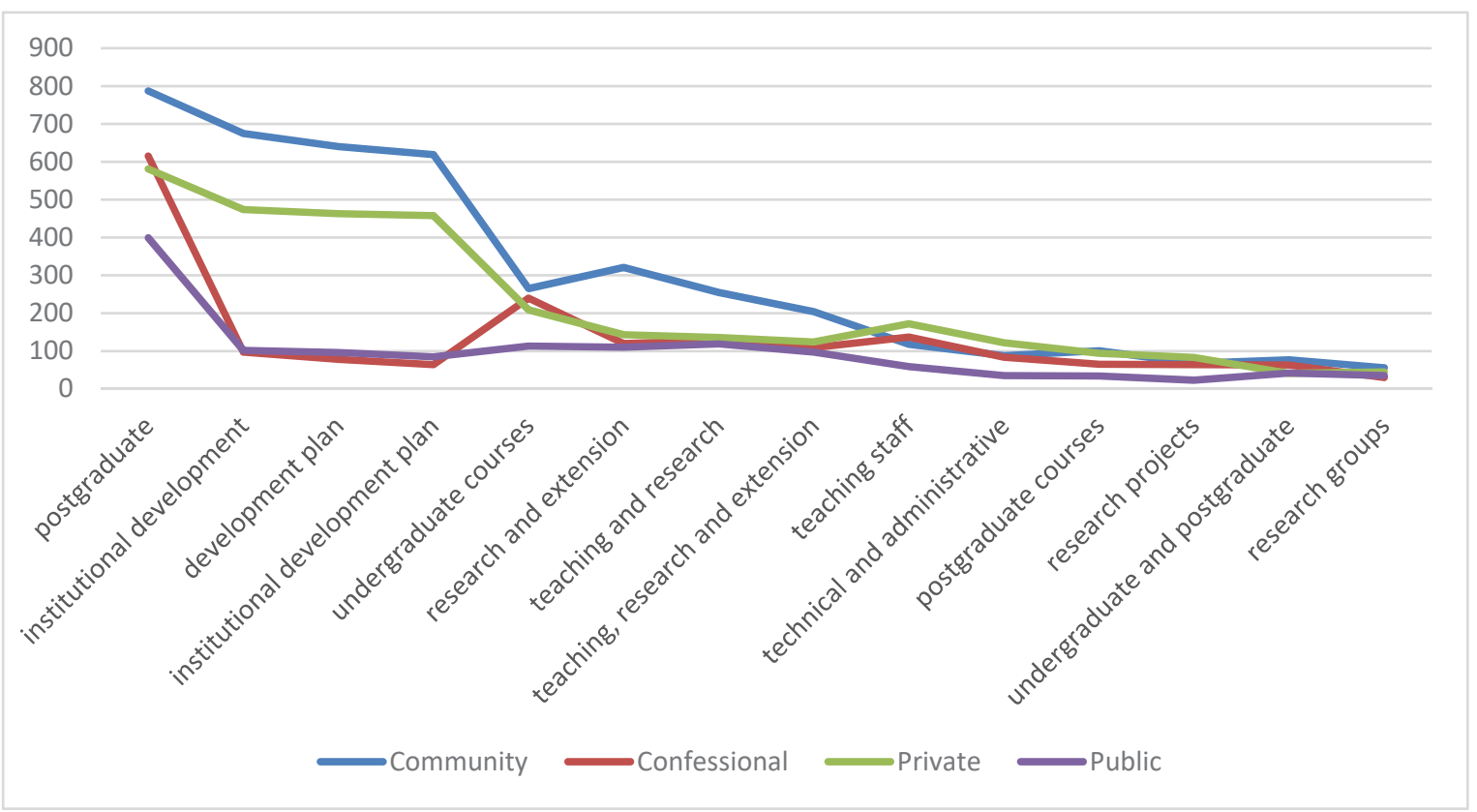

Figure 3. List of terms by type of HEI.

Source: Prepared by the authors.

The first dimension has to do with questions regarding the organizational profile, organizational management, and financial and budgetary aspects. When these elements are treated and aligned adequately, they are key factors that support organizational strategy or even for generating a value proposition.

The second dimension involves issues that constitute the end activities, addressing the academic organization, academic infrastructure (research, teaching and extension) and evaluation and monitoring of academic activities. These two macro-dimensions concomitantly conducted the process of identifying the first and second-order categories and, finally, the theoretical constructions that emerged in the final stage of the analysis (Chart 2) to provide a foundation for the results.

\subsection{Dimension I: Organizational Mission, Management and Investments}

The textual content of the IDPs of the universities, irrespective of their quadrant, converge with regard to their social role, mainly their impact on their respective communities through their end activities: i.e., teaching, research and extension. In this sense, they all share the idea that education "cannot be separated from the policies and purpose of the societies in which educational organizations conduct their activities of forming and building knowledge and citizenship" (Dias Sobrinho \& Ristoff, 2003, p. 150).

The textual content also highlights their social involvement in that the documents focus on describing their purposes regarding social inclusion and social responsibility, with these aspects being transposed in their essence to their respective missions. It is highlighted that mission and vision are closely related to the strategic aspects of the organizations in general, and in universities, mainly to consolidate their identity, serving as a basis for setting targets and goals. In this respect, a contrasting issue is highlighted in the documents. Whereas the missions of most organizations 
BBR

17

86

are translated clearly and objectively, to the point of being able to direct their decision-making processes and facilitate the unfolding of their actions, in the universities in question, it is perceived that the missions were established in a very vague and intangible way. This suggests serious difficulties in defining more objective and strategic goals, including in the private universities.

Their missions are mainly focused on research (knowledge creation), teaching (knowledge transmission), and extension (transfer of benefits to society) and their relationship with the community, denoting that universities have a very broad "field of action", operating in different environments and with diverse resources, thereby hindering the differentiation and focus of their end activities. Baldridge (1982) claims "Goal ambiguity is common in academic organizations. Most organizations know what they do. On the contrary, colleges and universities have vague ambiguous goals and they must build decision structures that grapple with uncertainty and conflict over those goals" (p. 25). With efforts to generate normative declarations, the goals of universities tend to produce missions that lack meaning or are dubious (Cohen \& March, 1974 , p. 195). "Thus, the ambiguity, complexity and incompatibility of the goals of university organizations constitute one of their main characteristics, which generates a decision-making process with little accuracy and poor articulation" (Andrade, 2002, p. 3).

Once the "mission" of the universities has been characterized with its idiosyncrasies and similarities, attention is focused on the philosophical, technical, and methodological principles that guide academic practices, and the didactic and pedagogical organization of the universities: i.e., the Institutional Pedagogical Project (IPP). The purpose of the IPP is to show the differentiation and originality of the university, guiding its academic, political, and administrative decisions, and defining the quality that the university desires to imprint on its teaching, research, and extension. In this sense, it is perceived that the universities seek to take new requirements from society into consideration, and thus define a direction for their teaching, respecting the specific aspects and singularities of the different courses and segments involved. Nevertheless, there is a convergence of themes in the documents. There is concern over the creation of conditions that allow students to interact with social processes, and the use of innovation in teaching activities, seeking to add new technologies to educational methodologies. There is a social commitment and the ethical and political responsibility of the university, in regards to the academic qualifications it offers. The evaluation of learning includes mechanisms capable of gauging the solidification of the intended academic profile. Actions are promoted to guarantee disabled people the ability to access and remain at the university. There is also concern over how the knowledge created at the universities is diffused, enabling better living conditions for the people involved in them. There is also a description of the professional profile formed through the courses on offer.

An analysis of the IPPs revealed "controlled freedom". In other words, although the IPP is a document that seeks to characterize and differentiate the university, its content must take into account the guidelines of the National Curricular Directives on the principles that guide the organization of IPPs. These are flexibility, contextualization, competence, problematization and interdisciplinarity. To this end, the universities use guiding documents, drafted by the MEC, which establishes that HEIs should, in the drafting of their pedagogical projects, clearly define the elements that support the conception of the course, its full curriculum and its operationalization, highlighting the following elements without losses to others.

These guidelines were explained in reports from the universities in question, with these manifestations occurring to a greater or lesser extent in their documents, as follows: 
Teaching strategies should be chosen based on the type of content and should promote the qualification of students so that they achieve the desired graduate profile. In this sense, the National Curricular Directives of all courses have shown a curriculum that enables a generalist graduation that is adaptable to new and emerging situations (Confessional University)

University courses are organized to offer students theoretical and practical frameworks that help them acquire cognitive competencies, skills and attitudes (...). It should be remembered that these theoretical and practical frameworks are always aligned with the National Curricular Directives of courses (...) in keeping with the guidelines of the National Education Council (CNE). (Private University).

The Pedagogical Project of the Course should consider the set of organizational and operational directives that express and guide the pedagogical practice of the course (...), obeying the national curricular directives established by the MEC (...). (Community University).

The economic, financial and budgetary aspects, academic and administrative organization of the organizational structure and decision-making, collegiate bodies and forms of participation for professors and students in collegiate bodies are very similar in the universities in question. Their differences are basically due to their "size", since many of them are multi-campus universities. Therefore, their structure seeks to adapt to local features and needs, as well as to legislation, which sets some criteria to be followed through legal devices. As for economic and financial matters, they follow the same pattern, generally presenting an operational budget and earmarking resources. There are no more objective explanations linked to academic strategies. It should be highlighted that in many cases, the numbers are not presented.

\subsection{Dimension II: ACADEmic Organization, EVALUATION AND ACADEMic Installations}

In this dimension, the analysis focused on the classification of "academic organization", aspects directly related to the end-activities of universities, such as selection of content and evaluation process, innovative teaching practices, internship policies, distance learning, inclusive education policies, offering of courses (at all levels), and research and extension programs.

In this stage of the analysis, and especially in this dimension, one of the aspects that stood out was the strong impact of the regulatory system of the federal higher education system and the correlations with the process of constructing the IDP. In all the universities, the impact of the legal requirements was significant with regard to issues such as increasing the offering of courses and places, optimization of forms of entry to the university, stimulating teaching qualifications, increasing the number of courses, adding more physical space, modernizing laboratory infrastructure, expanding the library, continuous training for support staff, strengthening scholarship programs for students, and building policies to help students with special needs. Therefore, in the documents, only a few effective differences were found with regard to these items. In specific terms, such as "Innovative teaching practices", with the "freedom" they are given by the legislation, the universities seek to demonstrate their differentials:

(...) in addition to the differentiation of content we adopted as methodological innovations to optimize the achievement of activities by academics, (...) seeking to simulate aspects of reality, placing students close to real-life situations, enabling an immediate return regarding consequences, attitudes and decisions (...) (Private University) 
BBR

17

88

(...) The university also has differentiated curricular proposals in its undergraduate courses (...), it uses the Problem Based Learning (PBL) methodology and the organization of the curriculum is modular (...) it uses the Virtual Learning Environment (VLE) in order to incorporate new technologies into education, develop the autonomy of academics (...) (Community University)

(...) the university has been developing a series of projects, mainly operating at three levels: 1 . Entrepreneurial Education, (...); 2. Business incubator: (...); and 3. Innovation and Technology Nucleus (ITN), for the management of scientific and technological knowledge produced at the university (...) (Confessional University)

However, it should be emphasized that, depending on the level of "maturity" of the university and its academic organization, that which is "consolidated" in one is considered "innovative" in others.

Concerning their infrastructure, all the IDPs are more a document that lists and/or describes what the universities have in terms of assets than a strategic explanation involving these resources and structure. The few differences emerge in those universities that have been in the sector for longer, due to their size and the amount of resources they can generate/access or obtain (public universities).

With regard to organizational evaluation and monitoring, opinions converged concerning the construction of the IDP. The content of many IDPs explains that they bring benefits to universities, especially because they provide an opportunity for self-knowledge by giving a clearer idea of the goals to be achieved within a time horizon, providing universities with direction.

Others highlighted the importance of the essence of the document's content in the sense of positioning the skills of the university with regard to concerns of the context of higher education. In this sense, the document is configured as the central tool for the management as a whole, but also for the academic management, as it becomes a guiding tool for teaching, research and extension, converging to achieve the common goals of universities and regulatory agencies of Brazilian higher education.

Institutional Evaluation as a permanent process of self-knowledge and reflection, with a view to improving the quality of teaching, research, extension and administrative management. It is not an evaluation for the purposes of domination, classification, punishment or rewards. It is a diagnostic evaluation for the purposes of planning, reviewing and orientation, and for perceiving the degree of distance between the proposed goals and the practice established in everyday institutional life. Thus, it is a tool that the university can use to effectively fulfil its mission and achieve its goals. (Community University)

The university considers the qualification of professionals in different fields of knowledge (...) This stance is reflected in the institution of its Own Evaluation Committee (OEC), which continues the works already developed in the Institutional Evaluation of the university, including in its discussions "thoughts on education" and "thoughts on the project of forming the men and society" of its community. (Private University)

The evaluation must result in greater involvement of the community and, consequently, a greater commitment to its results. An analysis of the strategies used, the difficulties encountered and the advances made should be conducted every year. (Public University) 


\section{DISCUSSION}

In accordance with the model presented (Figure 1, Situation A), the contribution of this study lies, on the one hand, in the findings regarding how the inherent characteristics of universities (Baldridge, 1983; Cohen \& March, 1974; Weick, 1983) have a limited impact on the quality of their management in decision-making processes. In more specific terms, how these characteristics affect the initiatives or actions that focus on the process of constructing and using the IDP as a document to provide strategic guidance to universities. On the other hand, the contribution lies in the implications in the IDPs related to external pressures of legitimacy and conformity (DiMaggio \& Powell, 1983; Meyer \& Rowan, 1977) suffered by the universities in their planning and execution activities. This hinders their strategic adaptation (Mintzberg, 1983; Pettigrew, 1987 ) and pushes them towards similarity or homogeneity through isomorphic mechanisms. In this sense, this work also contributes to a better understanding of how educational organizations tend to adopt similar symbolic elements (Hoy \& Miskel, 2008; Chan, 2016) in detriment of rational conduct in a competitive sector with increasingly greater expectations.

The results obtained show that under the perspective of Institutional Theory, Proposition "P1" (Situation "A" in Figure 1) was confirmed. Therefore, IDPs tend to be documents that seek to legitimize universities in relation to the other actors involved. In other words, they are not created and used due to institutional demands, but because they are legally required in accordance with the regulation (MEC, 2007).

It should be highlighted that these isomorphic mechanisms did not act exclusively or statically. As transformations occurred in the sector, the mechanisms followed dynamically and in a complementary fashion.

Because of the influence of the coercive mechanism, the higher education expansion policy, since the mid-1990s, has generated a constantly changing scenario that has affected the institutional field of universities. The legal issue, from the constitutional base to the LDB and other higher education regulations, has enabled private companies to operate in the sector, which was hitherto not the case. This had a direct impact on the number of private HEI. Due to this expansion, the SINAES became the "tool" for evaluating the national higher education system, establishing norms and monitoring sanctioned activities, gauging conformity and when necessary issuing punishments, among its other functions. In this context, universities are supervised and thus tend to comply with a set of laws decreed by the State through the MEC.

Under the normative influence, it was also seen that the universities needed to obtain legitimacy in the eyes of their more direct users, students and society, because of the implementation of the evaluation system. In this sense, they needed to present their "quality" through their installations, academic services, the result of their evaluations and especially their teaching staff. This mechanism, from one perspective, includes the norms and values that can be considered as standards, a reference for existing structures and behaviors. It can also be evaluated, specifying and defining targets or goals (DiMaggio \& Powell, 1983; Hoy \& Miskel, 2008; Cai, 2009; Chan, 2016).

From another perspective, isomorphic organizational changes can emerge, mainly through professionalization. The degree of professionalization tends to be the most important factor as a normative mechanism for consideration. It may be the result of formal education, especially in universities, or the formation and maintenance of work networks. In this respect, two aspects of professionalization may emerge. One is the support of formal education and the legitimacy of a cognitive base produced by university specialists (professors and researchers). The second aspect 
is the formation of professional networks that permeate organizations and through which new models are quickly spread (DiMaggio \& Powell, 1983; Hoy \& Miskel, 2008). To Scott (2008), professions can positively influence the university, i.e., they can act as the main social function of "creating, testing, transmitting and applying regulatory, normative and/or cognitive and cultural models" that are governed or govern another social sphere. These characteristics are found in the function of universities and are present in the documents.

Regarding the mimetic aspect, this may be linked to the significant growth in the number of new private universities in the sector in a relatively short time. In this case, it is reasonable to suppose that a pertinent action was to seek to imitate the actions of consolidated universities (public, confessional and community). It is also reasonable to suppose that when innovative and successful practices were achieved by new universities, these innovations were also copied by the older universities. It is understood that, with new practices being implemented by universities entering the market, they help to identify value in the eyes of consumers and act as a more attractive differential than those previously used by consolidated universities. Imitation may be encouraged by uncertainty, which acts as a powerful force. It may also emerge from the adoption of other organizations as a model, providing an incentive for reproduction (Miller-Millesen, 2003; Scott, 2008; Hoy \& Miskel, 2008; Cai, 2009; Chan, 2016).

\section{CONCLUSIONS OF THE STUDY}

The purpose of this article was to identify whether the strategic adaptations of HEIs, expressed in their IDPs, only reflect institutional pressures, leading them to converge their actions or characterize the strategic need to become differentiated through the development of their resources and capabilities. For this purpose, 20 IDPs were selected from Brazilian universities categorized as private, public, community, or confessional. The higher education sector in Brazil was then characterized, and this in turn detailed the relationship between the SINAES, the IDP, and the complex organization of the university. Two theories that contribute to understanding the external pressures suffered by universities were used, namely Institutional Theory and the Resource-Based View. Following the analyses, two propositions were presented, one claiming that organizational adaptation takes place through isomorphic mechanisms, or that adaptation is achieved through the better use of a university's resources and capabilities. Finally, there was a theoretical discussion and a discussion of the gaps left by the empirical articles on which the proposed model was based.

The importance of the study lies in its contribution to understanding the role and utility of the IDP as a document that consolidates organizational strategy and promotes a better understanding of the management of these organizations based on Institutional Theory and the Resource-Based View. Furthermore, its contribution is related to the literature on the Institutional-Based View (IBV), especially with the isomorphic mechanisms, as universities are subject to a restrictive legal framework and, therefore, institutional pressures. It was also possible to show that the institutional pressures on universities, which, due to their similarities or little differentiation in terms of structure and behavior, as seen in their respective IDPs, converge towards institutional isomorphism. In other words, the need of universities to be accepted in their environment because their values and behavior are coherent with the criteria and expectations of social actors (the state, students/community and professors). These similarities occurred, or were influenced by, the presence of coercive, mimetic and normative isomorphic mechanisms. 
A limitation of the study was the lack of greater depth and complementation in the analysis through interviews with participants in the IDP construction process. In this sense, a suggestion for future studies is the analysis of documents and interviews alongside the individual analyses of IDPs.

\section{REFERENCES}

Almino Francisco, T. H., Ramos, A. M., Otani, N., Helou, A. R. H. A., \& Michels, E. (2011). O impacto da estrutura legal do PDI no processo de planejamento estratégico de instituiçóes do sistema AMPESC. Revista Gestão Universitária na América Latina - GUAL, ed. esp., 133-162.

Andrade, R. A. (2002, julho/setembro). A universidade como organização complexa. Revista de Negócios, 7, 15-28.

Araújo, M. A. D. (1996, julho/agosto). Planejamento estratégico: Um instrumento à disposição das universidades? Revista de Administração Pública, 30(4), 75-81.

Baldridge, J. (1983). Organizational characteristics of colleges and universities. In J. Baldridge, \& T. Deal (Orgs.), The dynamics of organizational change in education. Berkeley: McUtchan.

Baldridge, J. (1982). Estruturación de políticas y liderazgo efectivo en la educación superior. México: Noema Editores.

Barbosa, P. R. (1996). Gestão de hospitais públicos: maior autonomia gerencial, melhor performance organizacional com apoio em contratos de gestão. Revista do Serviço Público. 2, 59-60.

Bardin, L. (2009). Análise de conteúdo. Lisboa: Ediçôes 70.

Barney, J. (1991). Firm resources and sustained competitive advantage. Journal of Management, 17(1), 99-120.

Barney, J. B., \& Hesterly, W. S. (2009). Strategic management and competitive advantage: Concepts and cases (3a ed.). Upper Saddle River, NJ: Prentice Hall.

Barney, J. B., \& Hesterly, W. S. (2011). Administração estratégica e vantagem competitiva: Conceitos e casos (M. Yamamoto, Trans.). São Paulo: Pearson Prentice Hall.

Brasil. (2004). Lei n. 10.861, de 14 de abril de 2004: Institui o Sistema Nacional de Avaliação da Educação Superior (SINAES) e dá outras providências.

Brasil. (2007). Instruçóes para elaboração de Plano de Desenvolvimento Institucional. Brasília, DF, Ministério da Educação. Disponível em http://www2.mec.gov.br/sapiens/pdi.html

Cai, Y. (2010). Global isomorphism and governance reform in Chinese higher education. Tertiary Educationand Management, 16(3), 229-241.

Carvalho, C. (2013). A mercantilização da educação superior brasileira e as estratégias de mercado das instituiçôes lucrativas. Revista Brasileira de Educaçâo, 18(54), 761-776.

Castor, B. V. J, \& Suga, N. (1988, January/March). Planejamento e ação planejada: O difícil binômio. Revista de Administração Pública, 22(1), 102-122.

Chamberlin, E. H. (1933). The theory of monopolistic competition. (8ed) Cambridge: Harvard University Press.

Chan, R. (2016). Studying philanthropy and fundraising in higher education: A proposed conceptual model. In H. C. Alphin, J. Lavine, S. Stark, \& A. Hocker, Facilitating higher education growth through fundraising and philanthropy. Hershey, PA: IGI Global. 
BBR

17

92

Christiano, A., Gohr, C., \& Gomes, M. (2016). Conhecimento como recurso estratégico em uma instituição de ensino superior: Uma análise sob a ótica dos professores. Informação \& Sociedade: Estudos, 26(1), 131-150.

Cohen, M., \& March, J. (1974). Leadership and ambiguity: The American college president (2a ed.). Boston: Harvard Business School Press.

Dalmagro, C., \& Rausch, R. (2012). Plano de desenvolvimento institucional de universidades federais brasileiras. Revista Administração: Ensino e Pesquisa, 13(3), 427-454.

Dias Sobrinho, J. (2008a). Avaliação educativa: Produção de sentidos com valor de formação. Avaliaçâo, 13(1), 193-207.

Dias Sobrinho, J. (2008b, novembro). Qualidade, avaliação: Do Sinaes a índices. Avaliação, 13(3), 817-825.

Dias Sobrinho, J., \& Ristoff, D. I. (2003). Avaliação e compromisso público: A educação superior em debate. Florianópolis: Insular.

Dimaggio, P., \& Powell, W. (1991). Introduction. In W. W. Powell \& P. J. DiMaggio (Eds.), The new institutionalism in organizational analysis (pp. 1-38). London: University of Chicago Press.

Dimaggio, P., \& Powell, W. (1983). The iron cage revisited: Institutional isomorphism and collective rationality in organizational fields. American Sociological Review, 48, 147-160.

Diniz, J. M. A., Mesquita, N. L., Assis, O. F. G., \& Tassigny, M. M. (2015). Encontros de iniciação científica em administração e o processo de institucionalização de uma Instituição de Ensino Superior. Revista UNIABEU, 8(20), 109-124.

Dussault, G. (1996, April/June). A gestão em serviços públicos de saúde: Características e exigências. Revista do Serviço Público, 26(2), p. 8-19.

Elpo, M. E. H. C. (2004). Avaliação da gestão universitária: Velhos problemas e novas perspectivas. In IV Colóquio Internacional sobre Gestão Universitária na América do Sul, 4, Anais. Florianópolis: INPEAU. Disponível em http://www.inpeau.ufsc.br/coloquio04/a4.htm

Fahy, J. (2000). The resource-based view of the firm: Some stumbling-blocks on the road to understanding sustainable competitive advantage. Journal of European Industrial Training, 24(2), 94-104.

Fiegenbaum, A., \& Thomas, H. (1993). Industry and strategic group dynamics: Competitive strategy in the insurance industry. Journal of Management Studies, 30(1), 69-105.

Folha de São Paulo. (2016). Ranking universitário Folha 2016. Educação, São Paulo. Disponível em http://m.ruf.folha.uol.com.br/2016/

Frauches, C. (2008). Diretrizes curriculares nacionais para os cursos de graduação. Brasília: ABMES.

Goulart, F. A. A., \& Cunha, R. E. (1999, julho/setembro). Da burocracia à ad hocracia. Revista do Serviço Público, (3), 59-60.

Hamel, G., \& Prahalad, C. K. (1995). Competindo pelo futuro: Estratégias inovadoras para obter o controle do seu setor e criar os mercados de amanhã. Rio de Janeiro: Campus.

Harvey, L., \& Williams, J. (2010, abril). Fifteen years of quality in higher education. Quality in Higher Education, 16, 1, 3-36.

Hawley, A. (1968). Human ecology. In D. L. Sills (Org.), International Encyclopedia of the Social Sciences (pp. 328-37). New York: Macmillan.

Hitt, M., Ireland, R., \& Hoskisson, R. (2011). Administração estratégica. São Paulo: Pioneira Thomson Learning. 
Ho, S. S-H., \& Peng, M. Y-P. (2016). Managing resources and relations in higher education institutions: A framework for understanding performance improvement. Educational Sciences: Theory \& Practice, 16(1), 279-300.

Hoopes, D. G., Madsen, T. L., \& Walker, G. (2003). Why is there a resource-based view? Toward a theory of competitive heterogeneity. Strategic Management Journal, 24(10), 889-902.

Hoy, K., \& Miskel, C. (2008). Educational administration: Theory, research and practice. New York, NY: Allynand Bacon.

Instituto Nacional de Estudos e Pesquisas Educacionais Anísio Teixeira. (2015, outubro). Educação superior. Instituto Nacional de Estudos e Pesquisas Educacionais Anísio Teixeira, Brasília. Disponível em http://inep.gov.br/web/guest/educacao-superior

Jarzabkowski, P., \& Felton, E. (2006). Strategizing and organizing in pluralistic contexts. Long Range Planning, 39, 631-648.

Junges, F. M. (2010). Gestão do conhecimento e a geração de vantagem competitiva sustentável em organizaçôes intensivas em conhecimento: Um estudo do setor de TI do Rio Grande do Sul (Dissertação de mestrado). Universidade do Vale do Rio dos Sinos, São Leopoldo.

Kast, F., \& Rosenzweit, J. E. (1987). Organização e administração: Um enfoque sistêmico. São Paulo: Pioneira.

Lanzillotti, V. S. (1997). Reengenharia na universidade: Uma interface possível? In A. Finger (Org.). Gestão de universidades: Novas abordagens. Curitiba: Champagnat.

Lehfeld, N., Gabarra, M., Costa, C., \& Silva Sousa, Y. (2010). Reflexôes sobre o processo de autoavaliação institucional: $\mathrm{O}$ olhar de uma comissão própria de avaliação. Avaliação, 15(1), 177-194.

Lobo \& Silva Filho, R. L. (2016). Gestão, financiamento e avaliação de qualidade nas instituiçóes universitárias. Disponível em http://www.abmes.org.br/abmes/publica/revista/estud18/est1806.htm

Maassen, P. A. M., \& Potman, H. P. (1990, agosto). Strategic decision making in higher education: An analysis of the decision-making aspects of the planning system in Dutch higher education (pp. 7-9). Center for Hihger Policy Studies (CHEPS), Ensched.

Mainardes, E., Ferreira, F., \& Tontini, G. (2009). Vantagens competitivas em instituições de ensino superior: Proposta e teste de um modelo. In IX Colóquio Internacional sobre Gestão Universitária na América do Sul, Anais. Florianópolis: INPEAU. Disponível em https:// repositorio.ufsc.br/handle/123456789/36803

March, J. G., \& Olsen, J. P. (1976). Ambiguity and choice in organizations. Bergen, Norway: Universitets-Forlaget.

Marchelli, P. S. (2007, July/September). O sistema de avaliação externa dos padróes de qualidade da educação superior no Brasil: Considerações sobre os indicadores. Ensaio: Avaliação e Políticas Públicas em Educação, 15(56), 351-372.

Mazzarol, T., \& Soutar, G. (1999). Sustainable competitive advantage for educational institutions: A suggested model. International Journal of Educational Management, 13(6), 287-300.

Ministério da Educação. (2014). Censo da Educação Superior, 2014: Resumo técnico. Instituto Nacional de Estudos e Pesquisas Educacionais, Brasília. Disponível em http://portal.inep.gov. $\mathrm{br} / \mathrm{web} /$ censo-da-educacao-superior/resumos-tecnicos

Meyer Jr. (2005) O planejamento universitário: ator racional, político ou simbólico: um estudo de universidades brasileiras. Revista Alcance. 12 (3), 373-389. 
BBR

17

94

Meyer Jr., V., \& Mangolim, L. (2006). Estratégia em universidades privadas. XXX ENANPAD, Salvador.

Meyer Jr., V., \& Lopes, M. C. B. (2003). Planejamento universitário: Mito e realidade. In XXI Simpósio Brasileiro, \& III Congresso Luso-Brasileiro de Política e Administração da Educação, Anais (pp. 10-20). Recife: ANPAE.

Meyer Jr., V., Pascucci, L., \& Mangolin, L. (2012, January/February). Gestão estratégica: Um exame de práticas em universidades privadas. $R A P, 46(1), 49-70$.

Meyer, J. W., \& Rowan, B. (1977). Institutionalized organizations: Formal structure as myth and ceremony. American Journal of Sociology, 83, 340-363.

Miller, D., \& Shamsie, J. (1996). The resource-based view of the firm in two environments: The Hollywood film studios from 1936 to 1965. Academy of Management Journal, 39(3), 519-541.

Miller-Millesen, J. (2003). Understanding the behavior of nonprofit boards of directors: A theory driven approach. Nonprofit and Voluntary Sector Quarterly, 32, 521-547.

Millet, J. (1962). The academic community. New York: McGraw-Hill.

Mintzberg, H. (1983). Power in and around organizations. Englewood Cliffs: Prentice-Hall.

Mintzberg, H. (1991). Mintzberg y la dirección. Madrid: Ediciones Diaz de Sants.

Mintzberg, H., \& Quinn, J. B. (2001). O processo da estratégia. Porto Alegre: Bookman.

Mintzberg, H., \& Rose, A. (2007). Strategic management upside down: McGill University, 18291980. In H. Mintzberg, Tracking strategies (pp. 283-317). New York: Oxford University Press.

Mizael, G. A., Pereira, J. R., Vilas Boas, A. A., \& Ferreira, M. F. A. (2012). Avaliação do plano de desenvolvimento institucional das universidades federais do consórcio do sul-sudeste de Minas Gerais. Revista Gestão Universitária na América Latina-GUAL, 5(4), ed. esp., 21-42.

Mondini, V. E. D., \& Domingues, M. J. C. (2005). Entendendo a classificação das IES no Brasil. In V Colóquio Internacional sobre Gestão Universitária na América do Sul, Anais. Mar del Plata. Disponível em https://repositorio.ufsc.br/xmlui/bitstream/handle/123456789/97136/ Vanessa\%20Edy\%20Dagnoni\%20Mondini.pdf?sequence=3\&isAllowed $=y$

Nieto, M., \& Perez, W. (2002). A firm's assets as a foundation for strategy. The Learning Organization, 9(1), 19-28.

Oliveira, J. F. (2002). A reestruturação da educação superior no Brasil e o processo de metamorfose das universidades federais: $O$ caso da Universidade Federal de Goiás (UFG) (Doctoral dissertation). Universidade de São Paulo, São Paulo.

Orton, J. D., \& Weick, K. E. (1990). Loosely coupled systems: A reconceptualization. The Academy of Management Review, 15(2), 203-223.

Penrose, E. (1959). The theory of the growth of the firm. Basil Blackwell and Mott, London.

Pettigrew, A. (1979). On studying organizational culture. Administrative Science Quarterly, (24), 570-581.

Pettigrew, A. (1987). Context and action in the transformation of the firm. Fournal of Management Studies. 24 (6), 649-670.

Picchiai, D. O. (2012, dezembro). Plano de desenvolvimento institucional e o projeto pedagógico institucional de universidades públicas: Limites organizacionais. Revista Gestão Universitária na América Latina - GUAL, 5(3), 23-45. 
Polidori, M. M.; Marinho-Araujo, C. M.; \& Barreyro, G. B. (2006). Sinaes: Perspectivas e desafios na avaliação da educação superior brasileira. Ensaio: Avaliação de Políticas Públicas em Educação, 14(53), 425-436.

Prahalad, C., \& Hamel, G. (1990). The core competence of the corporation. Harvard Business Review, 68(3), 79-91.

Ristoff, D. (2011). A expansão da educação superior brasileira: Tendências e desafios. In N. Fernández Lamarra \& M. F. C. Paula (Orgs.). La democratización de la educación superior en América Latina: Retos y posibilidades. Buenos Aires: EDUNTREF.

Robinson. J. (1933). The economics of imperfect competition. Londres:Macmilan.

Rodriguez, L. L. (1983). Novos enfoques sobre administração universitária. Administração universitária em tempos de crise: Perspectiva para o ano 2000. III Congresso da Organização Universitária Interamericana, Salvador.

Salviani, D. (2010). Organização da educação nacional: Sistema e Conselho Nacional de Educação, Plano e Fórum Nacional de Educação. Revista Educação e Sociedade, 31(112), 769-787.

Samonetto, V., \& Campos, F. (2013). Análise de aspectos estratégicos para gestão de IES privada. In XXXIII ENEGEP, Anais. ABEPRO, Salvador.

Schwartzman, S. (1996). La universidad como empresa econômica. Valdavia: Universidad Austral de Chile.

Scott, W. R. (2001). Institutions and organizations (2a ed.). Thousand Oaks: Sage.

Scott, W.R. (2008). Organizations and Organizing: Rational, Natural and Open Systens. New Jersey: Prentice Hall.

Serra, F. A. R., Ferreira, M., Pereira, M. F., \& Lissoni, J. (2008). Evolução da pesquisa em RBV: Um estudo dos últimos EnANPAD's. Revista Brasileira de Estratégia, 1, 39-56.

Serra, F.; Ferreira, M.P.; Almeida, M. (2013). Organizational decline: A yet largely neglected topic in organizational studies. Management Research, 11 (2), 133-156.

Silva, J., Melo, P., \& Ramos, A. (2013). Contribuiçôes do PDI e do Planejamento Estratégico na Gestão de Universidades Federais. Revista Gestão Universitária na América Latina - GUAL, 6(3), 269-287.

Souza, V. C. (2017, julho). Qualidade na educação superior: Uma visão operacional do conceito. Avaliação, 22(2), 332-357.

Srivastava, R., Fahey, L., \& Christensen, H. (2001). The resource based view and marketing: The role of market-based assets in gaining competitive advantage. Journal of Management, 27(6), 777-803.

Thompson, J., \& Cole, M. (1997). Strategic competency: The learning challenge. Journal of Workplace Learning, 9(5), 153-162.

Torres, F. R., \& Guimarães, T. de A. (2008). O papel de visitas técnicas na aprendizagem e institucionalização de práticas de controle externo. Brazilian Business Review, 5(1), 6985. doi:10.15728/bbr.2008.5.1.5

Voss, C., Blackmon, K., Chase, R., Rose, E., \& Roth, A. V. (1997). Service competitiveness: An Anglo-US study. Business Strategy Review, 8(1), 7-22.

Vught, F. A. van. (1988, agosto). Flexibility production and pattern management: Two basic instruments of strategic planning for higher education (pp. 7-8). Center for Higher Policy Studies (CHEPS), Enschede. 
BBR

17

96

Weick, K. E. (1976). Educational organizations as loosely coupled systems. Administrative Science Quarterly, (21), 1-19.

Weick, A. (1983). Issues in overturning a medical model of social work practice. Social Work, 28(6), 467-471.

Wernerfelt, B. (1984, abril/junho). A resource-based view of the firm. Strategic Management Journal, 5(2), 171-180. 